\title{
Sighting of the western gentle lemur Hapalemur griseus occidentalis in north-west Madagascar
}

The grey gentle lemur Hapalemur griseus is currently divided into three subspecies. Of these, very little is known about the western gentle lemur H. g. occidentalis and survey work to assess its distribution and numbers is urgently needed. The sighting of this species approximately $200 \mathrm{~km}$ to the south and $200 \mathrm{~km}$ to the north of the previously recorded populations further highlights this need. The Tsiombikibo Forest, where Hapalemur was sighted, may harbour further surprises and should be investigated more extensively in order to assess habitat condition and the species present.
The western gentle lemur Hapalemur griseus occidentalis, Family Lemuridae, is the smallest of the three recognized subspecies of $H$. griseus. The gentle lemur is reported to live in groups of 2-5 individuals and is crepuscular and/or cathemeral. The nominate subspecies, H. g. griseus, is found throughout the eastern rain forests and $H . g$. alaotrensis is restricted to the reed beds and surrounding marshes of Lake Alaotra (Figure 1; Petter et al., 1977; Tattersall, 1982; Harcourt and Thornback, 1990).
Figure 1. Distribution of Hapalemur griseus and sighting of Hapalemur griseus occidentalis (Hgo). Adapted from: Tattersall (1982); Carte de Madagasikara 1:500 000 (Anon., 1986); Nicoll and Langrand (1989); Mittermeier et al. (1992).

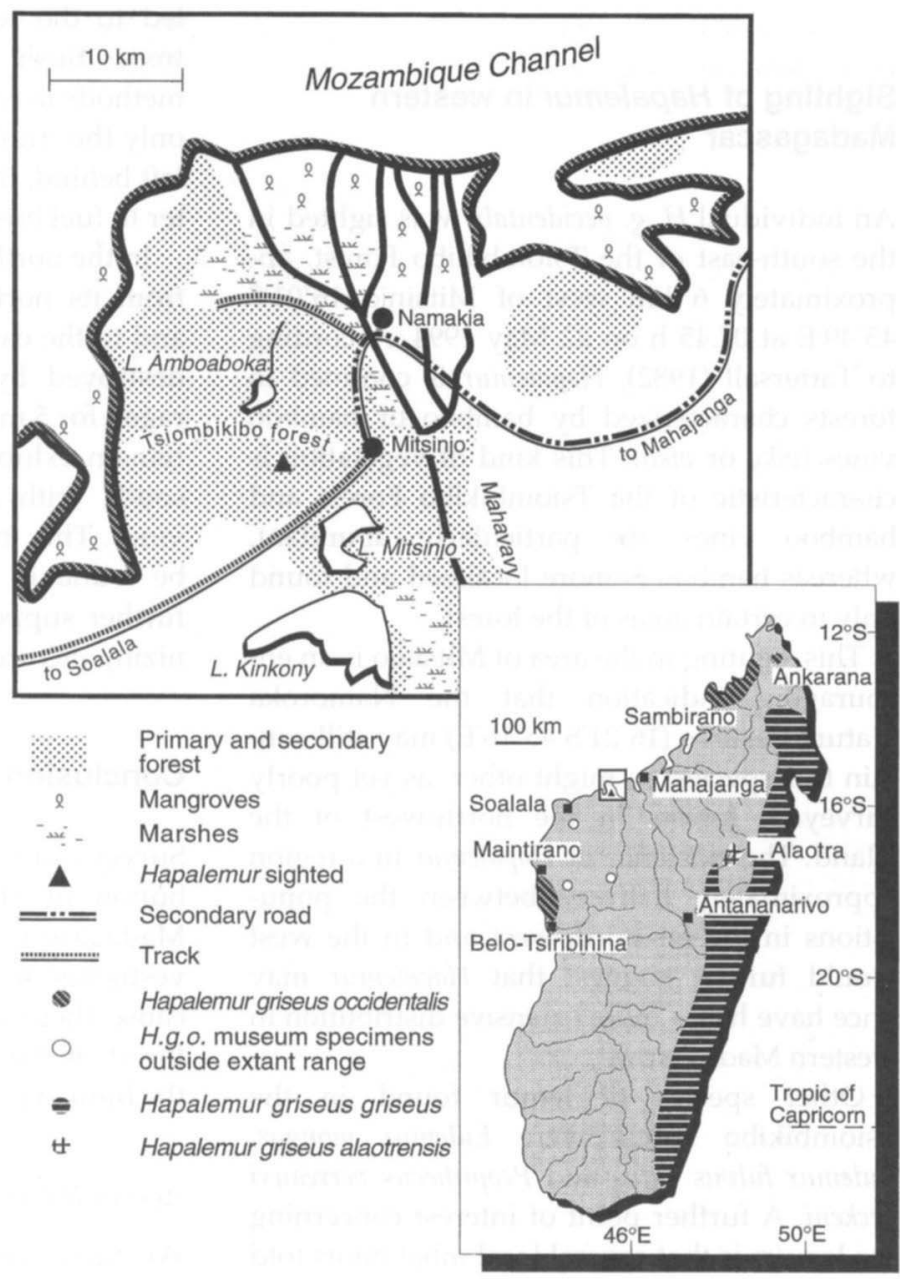


Isolated populations of the western gentle lemur are found in western Madagascar between Maintirano and Belo-Tsiribihina in the Sambirano region and in Ankarana Special Reserve, north-western Madagascar (Tattersall, 1982; Mittermeier et al., 1992). Collecting records from outside the extant range exist from localities to the east of the Maintirano/ Belo-Tsiribihina population and from the Namoroka area, $50 \mathrm{~km}$ south of Soalala, but the species is now presumed to be absent from these areas (Figure 1; Tattersall, 1982). Although $H . g$. occidentalis is classified as vulnerable, more information concerning its numbers and distribution in the wild is needed to ascertain its conservation status (Harcourt and Thornback, 1990; Mittermeier et al., 1992).

\section{Sighting of Hapalemur in western Madagascar}

An individual $H . g$. occidentalis was sighted in the south-east of the Tsiombikibo Forest, approximately $6 \mathrm{~km}$ west of Mitsinjo $16^{\circ} 01^{\prime} \mathrm{S}$ $45^{\circ} 49^{\prime} \mathrm{E}$ at $07.45 \mathrm{~h}$ on 22 May 1994. According to Tattersall (1982), Hapalemur is confined to forests characterized by bamboo or bamboo vines (viky or viko). This kind of vegetation is characteristic of the Tsiombikibo Forest and bamboo vines are particularly abundant, whereas bamboo is more localized and found only in certain areas of the forest.

This sighting in the area of Mitsinjo is an encouraging indication that the Namoroka Nature Reserve ( $\left.16^{\circ} 21^{\prime} \mathrm{S} 45^{\circ} 16^{\prime} \mathrm{E}\right)$ may still contain this species, as might other, as yet poorly surveyed, forests in the north-west of the island. The existence of Hapalemur in a region approximately halfway between the populations in the far north-west and in the west would further suggest that Hapalemur may once have had a more extensive distribution in western Madagascar.

Other species of lemur found in the Tsiombikibo Forest were Eulemur mongoz, Eulemur fulvus rufus and Propithecus verreauxi deckeni. A further point of interest concerning the lemurs is that several local inhabitants told us that the aye-aye Daubentonia madagascariensis is to be found in this forest.

\section{Vegetation}

Tsiombikibo Forest is highly degraded in the regions visited by the authors. As a result, access to the interior is exceedingly difficult and lack of time ruled out a search for an easy entry into the forest. The south-eastern extremities consist of secondary forest with dense undergrowth and a canopy of up to 7-8 $\mathrm{m}$ high. Where no forest remains, vegetation consists of dense shrubs and vines, interspersed by clearings, both of which are a result of bush fires. Any remaining emergent trees are $15-20 \mathrm{~m}$ tall, but selective logging has led to the removal of the majority of these trees. Bush fires are 'encouraged' by the methods used in extracting these trees because only the trunks are taken out and all branches left behind, thus providing abundant dry matter to fuel bush fires during the dry season.

In the north-east of the original forest range, from its northern limit to Lake Amboaboka and to the east of the lake, the forest has been destroyed by bush fires, the last of which raged for 5 months in 1993. The fragments that remain exhibit the same vegetation as in the south, with abundant bamboo and bamboo vines. This indicates that Hapalemur may also be found in this region, a possibility that is further supported by local inhabitants recognizing pictures of animals.

\section{Conclusion}

Surveys are needed to determine the distribution of $H$. g. occidentalis in north-western Madagascar. Tsiombikibo Forest should be investigated for an extended period of time, because there are probably still intact areas of forest in the interior and in the west, where the human population is less dense

\section{Acknowledgements}

We thank the Malagasy governmental insti- 
tutions (MINESup, DEF, MRSTD) for permission to conduct this project. Financial support was provided by the A. H. Schultz Foundation, G. \& A. Claraz-Donation, Goethe Foundation and the Swiss Academy of Science. Thanks go to Bob Martin, Louise Humphrey and Caroline Nievergelt for their comments on the manuscript.

\section{References}

Anonymous. 1986. Carte de Madagasikara 1:500 000. FTM, Institut National de Géodésie et Cartographie, Antananarivo.

Harcourt, C. and Thornback, J. 1990. Lemurs of Madagascar and the Comoros: The IUCN Red Data Book. IUCN, Gland, Switzerland and Cambridge, UK.

Mittermeier, R.A., Konstant, W.R., Nicoll, M.E. and Langrand, O. 1992. Lemurs of Madagascar: An Action Plan for their Conservation 1993-1999. IUCN, Gland, Switzerland.
Nicoll, M.E. and Langrand, O. 1989. Madagascar: Revue de la Conservation et des Aires Protégées. WWF, Gland, Suisse.

Petter, J.J., Albignac, R. and Rumpler, Y. 1977. Faune de Madagascar, Vol. 44: Mammiferes Lémuriens. Orstom, CNRS, Paris.

Tattersall, I. 1982. The Primates of Madagascar. Columbia University Press, New York.

Deborah J. Curtis, Anthropological Institute, University of Zürich-Irchel,

Winterthurerstr. 190, 8057 Zürich, Switzerland

Alphonse Zaramody, Département des Sciences de la Terre, Université de Mahajanga, Mahajanga 401, Madagascar

Olivier D. Rabetsimialona, Hotel Salama, Mitsinjo, Madagascar 